\title{
PENTINGNYA PENGENDALIAN INTERNAL UNTUK MENINGKATKAN TRANSPARANSI DAN AKUNTABILITAS PENGELOLAAN KEUANGAN DAERAH
}

\section{THE IMPORTANCE OF INTERNAL CONTROL TO IMPROVE TRANSPARENCY AND ACCOUNTABILITY OF REGIONAL FINANCIAL MANAGEMENT}

\author{
Ratna Purnama Sari ${ }^{1}$, Citra Setia Mulyani ${ }^{2}$, Dekeng Setyo Budiarto ${ }^{3}$ \\ ${ }^{1,2,3}$ Universitas PGRI Yogyakarta \\ 1'ratnaps@upy.ac.id, ${ }^{2}$ citrasetiam@gmail.com, ${ }^{3}$ dekengsb@upy.ac.id
}

\begin{abstract}
Abstrak
Transparansi dan akuntabilitas manajemen keuangan adalah bagian penting untuk mewujudkan tata kelola yang baik. Penelitian ini bertujuan untuk mengetahui pengaruh penyajian laporan keuangan daerah, aksesibilitas, dan pengendalian internal terhadap transparansi dan akuntabilitas pengelolaan keuangan di SKPD Kabupaten Klaten. Jenis penelitian ini adalah penelitian kuantitatif dengan cakupan populasi seluruh SKPD di Kabupaten Klaten. Teknik pengambilan sampel menggunakan metode purposive sampling dengan kriteria tertentu. Responden adalah 64 karyawan SKPD di Kabupaten Klaten. Hasil analisis menunjukkan bahwa: 1) penyajian laporan keuangan dan aksesibilitas tidak memiliki pengaruh signifikan terhadap transparansi dan akuntabilitas dalam mengelola laporan keuangan daerah; 2) kontrol internal memiliki dampak signifikan pada transparansi dan akuntabilitas dalam mengelola laporan keuangan regional.
\end{abstract}

Kata Kunci: Penyajian Laporan Keuangan, Aksesibilitas, Kontrol Internal, Transparansi, Akuntabilitas.

\begin{abstract}
Financial management transparency and accountability are an essential part of realizing good governance. This study aims to determine the effect of the presentation of regional financial statements, accessibility, and internal control on financial management transparency and accountability in SKPD of Klaten Regency. This type of this research is a quantitative study with the population covering of all SKPD in Klaten Regency. The sampling technique is using the purposive sampling method with specific criteria. The respondents were 64 SKPD employees in Klaten Regency. The results of the analysis show that: 1) the presentation of financial statements and accessibility does not have a significant effect on transparency and accountability in managing regional financial statements; 2) internal control has a significant impact on transparency and accountability in managing regional financial statements.
\end{abstract}

Keywords: Presentation Of Financial Statements, Accessibility, Internal Control, Transparency, Accountability.

\section{PENDAHULUAN}

Otonomi daerah diberlakukan di Indonesia sebagai bagian dari good govermance dengan tujuan agar kesejahteraan masyarakat melalui pemberdayaan potensi dapat dilakukan secara optimal. Otonomi daerah merupakan hak dan wewenang suatu daerah dalam mengatur, mengurus, dan mengelola sediri urusan pemerintahan dan masyarakat termasuk didalamnya adalah pengelolaan keuangan. Pengelolaan keuangan yang diwujudkan dalam bentuk laporan keuangan akan memberikan informasi tentang perencanaan dan pengelolaan keuangan daerah. Informasi tersebut memberikan kepercayaan bagi pengguna mengenai tata kelola pemerintahan yang baik (Rasuli \& Silfi, 2015; Yuliani, 2017). Sebagai bagian dari perwujudan akuntabilitas, laporan keuangan harus disajikan secara lengkap dan dapat dipertanggungjawabkan (Sande, 2013).

Pemerintah dikatakan memiliki tata kelola yang baik (good governance) jika seluruh aktivitasnya dilakukan secara transparan dan akuntabel. Tranparansi merupakan kebebasan dalam mengakses aktifitas pemerintah daerah baik dari segi keuangan, program, maupun pengambilan 
keputusan. Akuntabilitas merupakan bentuk dari pertanggungjawaban integritas keuangan, pengungkapan, dan ketaatan terhadap peraturan undang-undang. Jadi, dapat disimpulkan bahwa transparansi dan akuntabilitas merupakan prinsip keterbukaan yang memungkinkan masyarakat dapat memperoleh informasi mengenai pengelolaan keuangan daerah dan bentuk perwujudan dari pertanggungjawaban atas pengedalian sumber daya yang dimiliki dalam rangka pencapaian tujuan pemerintahan (Masyhur \& Silfi, 2017).

Aksesibilitas laporan keuangan daerah ditunjukkan dengan adanya kemudahan bagi masyarakat untuk mengetahui dan menemukan informasi yang dibutuhkan (Putri, Anisma, \& Al Azhar, 2017). Aksesibilitas juga dapat dikatakan sebagai wujud dari transaparansi pemerintah daerah yang dapat diakses melalui media massa seperti website pemerintah daerah (Yuliani, 2017). Laporan keuangan pemerintah daerah dapat dikatakan memenuhi prinsip-prinsip transparansi dan akuntabilitas jika laporan keuangan mudah dapat diakses oleh pengguna laporan keuangan pemerintah daerah (Hehanussa, 2015).

Pemerintah daerah dituntut untuk melakukan tata kelola yang akuntabel dan transparan dalam penyelenggaraan pemerintah daerah yang diwujudkan dengan pengendalian internal yang baik (Salle, 2016). Pengendalian internal merupakan bentuk pengendalian atas kegiatan pemerintah dan sumber daya yang dimiliki yang bertujuan untk mendapat keyakinan atas efektivitas dan efesiensi organisasi serta bentuk ketaatan pemrintah daerah. Pengendalian internal yang dilakukan harus memenuhi beberapa unsur yaitu, lingkungan pengendalian, penilaian risiko, kegiatan pengendalian, informasi dan komunikasi, serta pemantauan. Unsur-unsur pengedalian internal harus dilakukan oleh pemerintah daerah sehingga dalam pelaksanaan pengendalian internal dapat berjalan secara tepat, efektif dan efisien. Pengendalian internal diwujudkan dalam bentuk SPIP (Sistem Pengendalian Internal Pemerintah) sesuai PP No 60/2018 yang bertujuan untuk memberikan keyakinan mengenai keandalan pelaporan keuangan pemerintah, dan ketaatan pemerintah daerah terhadap peraturan perundang-undangan (Ledo \& Ayem, 2017).

Penelitian ini menarik karena, pertama temuan riset-riset sebelumnya yang tidak konsisten. Beberapa riset menyatakan bahwa penyajian laporan keuangan, aksesibilitas dan pengendalian internal berperpengaruh terhadap transaparansi dan akuntabilitas pengelolaan keuangan (Andriyani, Nur, \& Anggraini, 2016; Azlina \& Hasan, 2016; Masyhur \& Silfi, 2017; Nugraha \& Susanti, 2010), namun temuan riset lain menyatakan bahwa bahwa penyajian laporan keuangan, aksesibilitas dan pengendalian internal tidak berperpengaruh terhadap transaparansi dan akuntabilitas pengelolaan keuangan (Ledo \& Ayem, 2017; Sari \& Azlina, 2017). Kedua, pemerintah daerah di Indonesia pada saat ini masih belum secara keseluruhan mendapatkan predikat nilai terbaik atas laporan keuangan yang disajikan (Kemenpan.go.id). Ketiga, Laporan keuangan yang disajikan oleh pemerintah daerah saat ini masih banyak ditemukannya permasalahan oleh BPK sehingga mengeluarkan jugedment wajar dengan pengecualian (WDP) dan tidak mengemukakan pendapat (www.bpk.go.id).

\section{Landasan Teori}

Penyajian laporan keuangan sektor publik merupakan suatu output yang dihasilkan oleh pemerintah daerah atas kinerja keuangan pemerintah dalam satu periode berjalan. Penyajian laporan keuangan memberikan informasi mengenai posisi laporan keuangan atas transaksi yang terjadi (Putri, Anisma, \& Al Azhar, 2016). Tujuan dari penyajian laporan keuangan sektor publik yaitu:

1) Menyediakan informasi mengenai keuangan pemerintah daerah sebagai bahan pertimbangan dalam pengambilan keputusan.

2) Menyajikan sumber daya yang dimiliki pemerintah daerah dan penggunaan keuangan daerah.

3) Menyajikan informasi bagi pihak ekternal dalam mendanai kebutuhan yang diperlukan dan bagainama pihak berkepentingan melaksanakan kewajibannya.

4) Menyediakan informasi mengenai kondisi keuangan pemerintah daerah selama satu periode berjalan.

5) Menyediakan informasi mengenai kinerja pemerintah dalam mewujudkan tujuan secara efektif dan efisien serta sebagai bahan evalusasi atas kinerja pemerintah daerah (Rahma, Agusti, \& Wiguna, 2018).

Aksesibilitas laporan keuangan daerah merupakan fasilitas yang disediakan oleh pemerintah daerah untuk meningkatkan kemampuan laporan keuangan daerah dalam memberikan informasi 
secara relevan dan lengkap kepada pengguna laporan keuangan secara mudah. Laporan keuangan daerah tidak semata disampaikan dan dilaporkan kepada pusat semata namun, juga kepada masyarakat dan pihak ekternal sebagai bentuk transparansi pemerintah daerah, sehingga diharapkan mampu meningkatkan akuntabilitas atas laporan keuangan daerah. Aksesibilitas laporan keuangan yang tinggi merupakan tingkat kemudahan mendapatkan informasi secara mudah mengenai kondisi keuangan pemerintah. Hal ini dapat meminimalisir terjadinya kecurangan yang secara tidak langsung melakukan pemantauan atas kegiatan dan aktivitas pemerintah daerah. Fasilitas yang disediakan oleh pemerintah daerah dapat diwujudkan melalui media massa pemerintah yaitu website pemerintah daerah, sehingga dapat meningkatkan transparansi laporan keuangan daerah (Yuliani, 2017).

Pengendalian internal merupakan suatu proses atau kegiatan yang dilakukan oleh pihak pemerintah daerah secara integral pada suatu tindakan dalam memantau pelaksanaan kegiatan secara terus menerus. Pengendalian internal dilaksanakan oleh pimpinan dan seluruh pegawai pemerintah daerah sehingga mampu memberi keyakinan bahwa kegiatan dan tujuan pemerintah daerah telah tercapai secara efektif dan efisien. Pengendalian internal terhadap laporan keuangan dilaksanakan untuk mengatur dan memantau keuangan pemerintah daerah sehingga mampu memberikan keandalan atas pelaporan keuangan. Pengendalian internal berguna untuk mengendalikan kegiatan pemerintah dalam mencapai pengelolaan keuangan pemerintah daerah yang efektif, efisien, transparan, dan akuntabel (D. Sari, 2012).

Transparansi dan akuntabilitas merupakan dua hal yang diperlukan untuk menyajikan laporan keuangan yang baik dan wajar serta dapat dipertanggungjawabkan. Laporan keuangan yang transparan dapat memberikan pengaruh positif bagi pemerintah daerah yaitu memudahkan pemerintah daerah dalam mempublikasikan hasil kinerja keuangan, kegiatan, serta pengambilan keputusan selama periode berjalan kepada masyarakat. Pengungkapan yang dilakukan oleh pemerintah daerah atas laporan keuangan merupakan bentuk pencapaian atas kepuasan masyarakat dalam menggunakan laporan keuangan sehingga mampu menjaga transparansi dan akuntabilitas laporan keuangan pemerintah daerah (Grosso \& Van Ryzin, 2011). Akuntabilitas merupakan suatu pemberian informasi pengungkapan (disclosure) atas kegiatan keuangan, sehingga pelaporan keuangan yang akan dipertanggungjawabkan kepada pihak berkepentingan mendapatkan kepercayaan. Akuntabilitas pemerintah daerah merupakan bentuk keberhasilan maupun kegagalan atas pengelolaan keuangan pemerintah daerah (Ichlas, Basri, \& Arfan, 2014).

\section{Pengembangan Hipotesis}

Penyajian laporan keuangan daerah merupakan penyusunan laporan keuangan yang disajikan dengan tujuan pertanggungjawaban pemerintah atas ketepatan penyusunan keuangan pemerintah daerah (PP No.13 Tahun 2006). Laporan keuangan sektor publik merupakan komponen penting dalam menciptakan akuntabilitas sektor publik sehingga, penyusunan laporan keuangan pemerintah harus sesuai dengan standar akuntansi pemerintah yang berlaku (Rasuli \& Silfi, 2015). Beberapa hasil penelitian sebelumnya menyatakan bahwa penyajian laporan keuangan tidak berpengaruh terhadap akuntabilitas pengelolaan keuangan pemerintah daerah (Ledo \& Ayem, 2017; Sari \& Azlina, 2017). Namun hasil riset lain menyatakan bahwa penyajian laporan keuangan berpengaruh signifikan terhadap transparansi dan akuntabilitas pengelolaan keuangan daerah (Masyhur \& Silfi, 2017). Berdasarkan hasil temuan penelitian sebelumnya maka diajukan hipotesis sebagai berikut:

$\mathrm{H}_{1}$ : Penyajian laporan keuangan berpengaruh positif signifikan terhadap transparansi dan akuntabilitas pengelolaan keuangan daerah.

Aksesibilitas laporan keuangan daerah merupakan kemudahan mendapatkan infomasi mengenai kinerja pemerintah baik dari laporan keuangan, pengelolaan, maupun kegiatan pemerintah yang telah dipublikasikan. Penerapan akuntansi yang baik akan memudahkan masyarakat dalam memahami laporan yang dibutuhkan sehingga mampu meningkatkan tingkat transparansi dan akuntabilitas dari laporan keuangan pemerintah daerah (Putri et al., 2017). Hasil temuan Penelitian sebelumnya menyatakan bahwa aksesibilitas berpengaruh positif dan siginifikan terhadap transparansi pengelolaan laporan keuangan daerah (Azlina \& Hasan, 2016; Ledo \& Ayem, 2017). Semakin mudah akses yang diberikan pemerintah kepada masyarakat maka semakin transparan dan 
akuntabel laporan keuangan pemerintah daerah. Berdasarkan temuan diatas maka diajukan hipotesis sebagai berikut:

$\mathrm{H}_{2}$ : Aksesibilitas berpengaruh positif signifikan terhadap transparansi dan aksesibilitas pengelolaan keuangan daerah.

Pengendalian internal merupakan suatu proses yang dilakukan dan bertujuan untuk mengendalikan kegiatan pemerintah dalam rangka mencapai tujuannya. Pengendalian internal adalah salah suatu cara untuk mengukur, mengarahkan, serta mengawasi atas kegiatan pimpinan dan seluruh pegawai untuk memberikan keyakinan yang memadai, sehingga semakin baik pengendalian internal yang dilakukan oleh pemerintah maka pencapaian tujuan pemerintah yang efektif dan efisien akan tercapai (E. W. Sari \& Azlina, 2017). Hasil penelitian sebelumnya menyatakan bahwa terdapat pengaruh antara pengendalian internal terhadap akuntabilitas dan transparansi laporan keuangan pemerintah daerah daerah (Andriani, 2010; Nugraha \& Susanti, 2010). Untuk meningkatkan transparansi dan akuntabilitas keuangan daerah pemerintah daerah diwajibkan meningkatkan pengendalian internalnya, semakin baik pengendalian internal maka laporan keuangan daerah akan semakin akuntabel dan transparan (Salle, 2016). Berdasarkan hasil penelitian diatas maka diajukan hipotesis sebagai berikut:

$\mathrm{H}_{3}$ : Pengendalian internal berpengaruh positif signifikan terhadap transparansi dan akuntabilitas pengelolaan keuangan daerah.

\section{METODE}

Populasi penelitian ini adalah seluruh kepala Satuan Kerja Perangkat Daerah (SKPD), kasubag perencanaan, kasubag keuangan, dan bendahara SKPD Pemerintah Kabupaten Klaten yang berjumlah 24 SKPD. Data yang digunakan pada penelitian ini adalah data primer yang diperoleh dengan menyebarkan kuesioner kepada responden penelitian. Teknik pengambilan sampel menggunakan metode purporsive sampling dengan kriteria tertentu (Budiarto, 2019). Kriteria yang digunakan adalah: 1) pegawai yang berhubungan langsung dengan keuangan; 2) pegawai yang ikut serta dalam penyusunan anggaran keuangan daerah; 3) pengawai yang bekerja > 1 tahun; 4) pegawai dengan pendidikan minimal S-1. Penelitian ini dilakukan dalam waktu 2 bulan pada bulan November dan Desember 2018. Peneliti berhasil menyebarkan 96 namun hanya 64 kuesioner yang dapat dianalisis sisanya 32 kuesioner tidak kembali.

\section{Devinisi Operasional Variabel}

Penyajian laporan keuangan daerah merupakan bentuk pertanggungjawaban pemerintah daerah terhadap pemerintah pusat atas pengelolaan keuangan selama periode berjalan. Penyajian laporan keuangan daerah diukur dengan menggunakan 4 indikator yaitu: relevan, andal, dapat dipahami dan dibandingkan (Aliyah \& Nahar, 2012).

Aksesibilitas laporan keuangan daerah merupakan akses publik yang memberikan informasi kepada masyarakat dengan tujuan memberikan kepercayaan atas pengelolaan keuangan pemerintah kepada publik (Azlina \& Hasan, 2016). Pengukuran aksesibilitas diukur dari 2 indikator yaitu: 1) laporan keuangan dapat diakses, dan 2) laporan keuangan dipublikasi melalui media umum (Sande, 2013).

Pengendalian internal merupakan strategi yang dilakukan pemerintah untuk memastikan jalannya program sesuai dengan tujuan pemerintah serta memberikan keyakinan bahwa laporan keuangan telah disajikan secara wajar (Masyhur \& Silfi, 2017). Pengukuran pengendalian internal diukur berdasarkan 5 indikator yaitu: lingkungan pengendalian, penilaian risiko, kegiatan pengendalian, informasi dan komunikasi, serta pemantauan berdasarkan PP No.60 Tahun 2008 (E. W. Sari \& Azlina, 2017).

Transparansi dan Akuntabilitas merupakan prinsip keterbukaan kepada masyarakat mengenai pengelolaan keuangan pemerintah yang telah disusun sesuai dengan standar akuntansi pemerintah sehingga dapat digunakan serta dapat dipahami oleh pengguna (publik) dan pengambil keputusan yaitu pemerintah (Masyhur \& Silfi, 2017). Pengukuran transparansi dan akuntabilitas diukur menggunakan 8 indikator yaitu:

1) Pembuatan keputusan sudah memenuhi standar etika dan nilai-nilai yang berlaku; 
2) Kejelasan dari sasaran kebijakan yang diambil, dan sudah sesuai dengan visi dan misi organisasi, serta standar yang berlaku;

3) Mekanisme yang menjamin bahwa standar telah terpenuhi, dengan konsekuensi mekanisme pertanggungjawaban jika standar tersebut tidak terpenuhi;

4) Konsistensi maupun kelayakan dari target operasional yang telah ditetapkan maupun prioritas dalam mencapai target tersebut;

5) Penyebarluasan informasi mengenai suatu keputusan, melalui media massa, media nirmassa, maupun media komunikasi personal;

6) Terdapat akurasi dan kelengkapan informasi yang berhubungan dengan cara-cara mencapai sasaran suatu program;

7) Ketersediaan sistem informasi manajemen dan monitoring hasil yang telah dicapai pemerintah;

8) Mekanisme yang memfasilitasi pelaporan maupun penyebaran informasi maupun penyimpangan tindakan aparat publik didalam kegiatan melayani (Aliyah \& Nahar, 2012).

\section{HASIL DAN PEMBAHASAN}

\section{Hasil Uji Validitas Data}

Uji validitas data dilakukan dengan jumlah pertanyaan yang dibagi untuk tiga variabel independen dan variabel dependen yaitu, 7 pertanyaan untuk $\left(\mathrm{X}_{1}\right), 4$ pertnayaan untuk $\left(\mathrm{X}_{2}\right), 16$ pertanyaan untuk $\left(\mathrm{X}_{3}\right)$ dan 8 pertanyaan untuk $(\mathrm{Y})$

Table 1. Hasil Uji Validitas Variabel Penyajian Laporan Keuangan Daerah.

\begin{tabular}{clc}
\hline No & \multicolumn{1}{c}{ Pertanyaan } & \multicolumn{1}{c}{$\begin{array}{c}\text { Pearson } \\
\text { correlation }\end{array}$} \\
\hline 1 & $\begin{array}{l}\text { Informasi yang dihasilkan dari laporan keuangan SKPD telah } \\
\text { manggambarkan dengan jujur transaksi yang seharusnya disajikan } \\
\text { dalam laporan keuangan. }\end{array}$ & $0,703^{* *}$ \\
2 & $\begin{array}{l}\text { SKPD mampu menyusun laporan keuangan secara lengkap sesuai } \\
\text { dengan SAP yaitu: Laporan Realisasi Anggaran, Neraca, Laporan Arus }\end{array}$ & $0,570^{* *}$ \\
3 & $\begin{array}{l}\text { Kas dan Catatan Atas Laporan Keuangan. } \\
\text { Apabila dilakukan pengujian terhadap laporan keuangan lebih dari } \\
\text { sekali oleh pihak yang berbeda, hasilnya tetap sama. }\end{array}$ & $0,725^{* *}$ \\
4 & $\begin{array}{l}\text { Laporan keuangan mampu memberikan informasi mengenai kondisi } \\
\text { keuangan yang mudah dipahami oleh pengguna. }\end{array}$ & $0,716^{* *}$ \\
5 & $\begin{array}{l}\text { Informasi yang dihasilkan dalam laporan keuangan SKPD memenuhi } \\
\text { kebutuhan para pengguna laporan keuangan. }\end{array}$ & $0,859^{* *}$ \\
6 & $\begin{array}{l}\text { Informasi yang termuat dalam laporan keuangan dapat dibandingkan } \\
\text { dengan laporan keuangan periode sebelumnya. }\end{array}$ & $0,768^{* *}$ \\
7 & $\begin{array}{l}\text { Laporan keuangan yang disusun oleh SKPD telah dapat dijadikan } \\
\text { sebagai tolak ukur dalam penyusunan anggaran tahun berikutnya. }\end{array}$ & $0,753^{* *}$ \\
\hline
\end{tabular}

Keterangan: $* *$ Signifikan $<1 \%$

Tabel 2. Hasil Uji Validitas Variabel Aksesibilitas

\begin{tabular}{llc}
\hline No & \multicolumn{1}{c}{ Pertanyaan } & $\begin{array}{c}\text { Pearson } \\
\text { correlation }\end{array}$ \\
\hline 1 & $\begin{array}{l}\text { Laporan keuangan dipublikasikan secara terbuka melalui media massa. } \\
2\end{array}$ & $\begin{array}{l}\text { Memberikan kemudahan dalam memperoleh informasi tentang laporan } \\
\text { keuangan. }\end{array}$ \\
3 & $\begin{array}{l}\text { Masyarakat dapat mengakses laporan keuangan daerah melalui internet. } \\
\text { Instansi membuat pembatasan akses dan akuntabilitas terhadap sumber } \\
\text { daya dan catatan. }\end{array}$ & $0,622^{* *}$ \\
& $0,889^{* *}$ \\
\hline
\end{tabular}

Keterangan: $* *$ Signifikan $<1 \%$

Tabel 3. Hasil Uji Validitas Variabel Sistem Pengendalian Internal 


\begin{tabular}{llc}
\hline No & \multicolumn{1}{c}{ Pertanyaan } & $\begin{array}{c}\text { Pearson } \\
\text { correlation }\end{array}$ \\
\hline 1 & $\begin{array}{l}\text { Pimpinan melakukan penegakan integritas dan etika dilingkungan } \\
\text { intenal. }\end{array}$ & $0,617^{* *}$ \\
2 & Adanya kepemimpinan kondusif di lingkungan intern . & $0,766^{* *}$ \\
3 & Pimpinan membentuk struktur organisasi yang sesuai dengan & $0,566^{* *}$ \\
& kebutuhan . & $0,679^{* *}$ \\
4 & Pimpinan membagi wewenang dan pembebanan tanggung jawab. & $0,788^{* *}$ \\
5 & Pimpinan mewujudkan peran aparat pengawasan intern yang baik. & $0,678^{* *}$ \\
6 & dilakukannya identifikasi risiko. & $0,667^{* *}$ \\
7 & Melakukan analisis risiko. & $0,797^{* *}$ \\
8 & Terdapat mekanisme review dari pejabat tinggi untuk mengawasi & \\
& pencapaian instansi terhadap rencana yang telah dibuat. & $0,612^{* *}$ \\
9 & Terdapat pemisahan tugas dan tanggung jawab yang jelas. & $0,729^{* *}$ \\
10 & Dilakukannya review terhadap pencatatan atas semua transaksi. & $0,841^{* *}$ \\
11 & Sistem pengendalian intern, semua transaksi dan kejadian penting & \\
& lainnya telah didokumentasikan secara memadai. & $0,519^{* *}$ \\
12 & Informasi diidentifikasi, diperoleh, diproses dan dilaporkan melalui & \\
& suatu sistem informasi. & $0,569^{* *}$ \\
13 & Komunikasi antar bagian pada instansi telah dilakukan secara memadai. & $0,593^{* *}$ \\
14 & Instansi melaksanakan pemantauan berkelanjutan. & $0,691^{* *}$ \\
15 & Instansi melakukan evaluasi terpisah & $0,665^{* *}$ \\
\hline 16 & Instansi melakukan penyelsaian atas hasil pemeriksaan &
\end{tabular}

Keterangan: $* *$ Signifikan $<1 \%$

Tabel 4. Hasil Uji Validitas Variabel Transparansi Dan Akuntabilitas

\begin{tabular}{|c|c|c|}
\hline No & Pertanyaan & $\begin{array}{c}\text { Pearson } \\
\text { correlation }\end{array}$ \\
\hline 1 & $\begin{array}{l}\text { Pembuatan keputusan sudah memenuhi standar etika dan nilai-nilai } \\
\text { yang berlaku, artinya sesuai dengan prinsip-prinsip administrasi yang } \\
\text { benar maupun nilai-nilai yang berlaku bagi stakeholders. }\end{array}$ & $0,638^{* *}$ \\
\hline 2 & $\begin{array}{l}\text { Adanya kejelasan dari sasaran kebijakan yang diambil, dan sudah } \\
\text { sesuai dengan visi dan misi organisasi, serta standar yang berlaku. }\end{array}$ & $0,751 * *$ \\
\hline 3 & $\begin{array}{l}\text { Adanya mekanisme yang menjamin bahwa standar telah terpenuhi, } \\
\text { dengan konsekuensi mekanisme pertanggungjawaban jika standar } \\
\text { tersebut tidak terpenuhi. }\end{array}$ & $0,679 * *$ \\
\hline 4 & $\begin{array}{l}\text { Konsistensi maupun kelayakan dari target operasional yang telah } \\
\text { ditetapkan maupun prioritas dalam mencapai target tersebut. }\end{array}$ & $0,620 * *$ \\
\hline 5 & $\begin{array}{l}\text { Penyebarluasan informasi mengenai suatu keputusan, melalui media } \\
\text { massa, media nirmassa, maupun media komunikasi personal. }\end{array}$ & $0,764 * *$ \\
\hline 6 & $\begin{array}{l}\text { Terdapat akurasi dan kelengkapan informasi yang berhubungan dengan } \\
\text { cara-cara mencapai sasaran suatu program. }\end{array}$ & $0,728 * *$ \\
\hline 7 & $\begin{array}{l}\text { Ketersediaan sistem informasi manajemen dan monitoring hasil yang } \\
\text { telah dicapai pemerintah. }\end{array}$ & $0,620 * *$ \\
\hline 8 & $\begin{array}{l}\text { Mekanisme yang memfasilitasi pelaporan maupun penyebaran } \\
\text { informasi maupun penyimpangan tindakan aparat publik didalam } \\
\text { kegiatan melayani. }\end{array}$ & $0,700 * *$ \\
\hline
\end{tabular}




\section{Hasil Uji Reabilitas Data}

Pengujian atas reliabilitas data terhadap variabel independen dan variabel dependen dengan menggunakan Cronboach alpha $(\alpha)$ dengan standar koefisien 0,6. Hasil pengujian reabilitas menunjukkan vahwa seluruh variabel memiliki nilai cronbach alpha >0,6 (Tabel 4).

Tabel 5. Hasil Uji Reliabilitas

\begin{tabular}{llcc}
\hline No & \multicolumn{1}{c}{ Variabel } & Cronbach Alpha & Keterangan \\
\hline 1 & Penyajian laporan keuangan $\left(\mathrm{X}_{1}\right)$ & 0,832 & Reliabel \\
2 & Aksesibilitas $\left(\mathrm{X}_{2}\right)$ & 0,672 & Reliabel \\
3 & Pengendalian internal $\left(\mathrm{X}_{3}\right)$ & 0,919 & Reliabel \\
4 & Transparansi dan akuntabilitas $(\mathrm{Y})$ & 0,840 & Reliabel \\
\hline
\end{tabular}

Sumber: Data primer diolah tahun 2019

\section{Uji Hipotesis}

Berdasarkan hasil analisis pada seluruh intrumen maka dihasilkan pengujian hipotesis dengan uji t (parsial) yang bertujuan untuk mengetahui pengaruh variabel independen terhadap variabel dependen. Hasil pengujian hipotesis ditunjukkan pada tabel 6 sebagai berikut:

Tabel 6. Hasil Uji Hipotesis

\begin{tabular}{lcclc}
\hline \multicolumn{1}{c}{ Variabel } & Koef. Beta & t & Sig. & Keterangan \\
\hline $\begin{array}{l}\text { Penyajian } \\
\text { keuangan }\end{array}$ laporan & 0,106 & 0,845 & 0,401 & $\mathrm{H}_{1}$ : tidak terbukti \\
$\begin{array}{l}\text { Aksesibilitas } \\
\text { Pengendalian internal }\end{array}$ & 0,235 & 1,591 & 0,117 & $\mathrm{H}_{2}$ : tidak terbukti \\
\hline $\begin{array}{l}\text { F hitung: } 24,123 \\
\text { Adj R Square: } 0,524\end{array}$ & 0,335 & 4,452 & $0,000^{* * *}$ & $\mathrm{H}_{3}$ : terbukti \\
\hline
\end{tabular}

Keterangan: $* *$ Signifikan $<1 \%$

Berdasarkan hasil uji t pada tabel 6 dapat disimpulkan bahwa dua variabel independen yaitu penyajian laporan keuangan memiliki nilai signifikansi 0,401 (tidak signifikan) dan aksesibilitas memiliki nilai signifikansi 0,117 (tidak signifikan). Hasil penelitian ini membuktikan bahwa hipotesis 1 dan hipotesis 2 tidak terbukti. Sedangkan variabel independen pengendalian internal menujukkan berpengaruh positif terhadap transparansi dan akuntabilitas pengelolaan keuangan daerah dengan signifikansi sebesar 0,000 (hipotesis 3 terbukti).

Penyajian laporan keuangan daerah tidak berpengaruh terhadap transparansi dan akuntabilitas pengelolaan laporan keuangan daerah.

Hasil pengujian hipotesis menujukkan bahwa variable penyajian laporan keuangan daerah tidak berpengaruh terhadap transparansi dan akuntabilitas. Hasil penelitian ini mendukung penelitian sebelumnya yang menjelaskan bahwa penyajian laporan keuangan berpengaruh terhadap transparansi dan akuntabilitas laporan keuangan daerah (Ledo \& Ayem, 2017; Sari \& Azlina, 2017). Hal ini berarti bahwa penyajian laporan keuangan daerah belum disajikan secara memadai dan informasi dalam laporan keuangan belum disajikan secara relevan. Kondisi ini ditunjukkan dari hasil penelitian masing-masing SKPD bahwa laporan keuangan yang disajikan belum sesuai dengan standar akuntansi pemerintah dan beberapa SKPD masih belum mengerti secara keseluruhan dalam penyusunan laporan keuangan daerah.

\section{Aksesibiltas tidak berpengaruh terhadap transparansi dan akuntabilitas pengelolaan laporan keuangan daerah.}

Hasil pengujian hipotesis menunjukkan bahwa variabel aksesibilitas tidak berpengaruh terhadap transparansi dan akuntabilitas pengelolaan keuangan daerah. Aksesibiltas memberikan kemudahan bagi para pengguna laporan keuangan, aksesibilitas menjadi hal penting terciptanya akuntabilitas laporan keuangan daerah. Hal ini berarti bahwa, jika kemudahan dalam penggunaan 
laporan keuangan masih belum dilakukan secara maksimal maka usaha pemerintah dalam menciptakan akuntabilitas serta transparansi tidak berjalan dengan baik dan maksimal, hal ini dapat meurunkan kemampuan SKPD dalam mempublikasi atau memberikan informasi dengan akses yang mudah kepada pengguna laporan keuangan secara menyeluruh (Azlina \& Hasan, 2016).

\section{Pengendalian internal berpengaruh positif terhadap transparansi dan akuntabilitas pengelolaan laporan keuangan daerah.}

Hasil analisis menujukkan bahwa pengendalian internal berpengaruh signifikan terhadap transparansi dan akuntabilitas laporan keuangan daerah. Hasil penelitian ini disukung oleh temuan riset sebelumnya (Andriani, 2010; Nugraha \& Susanti, 2010). Apabila pengendalian internal dalam mengelolah keuangan daerah dapat dilakukan dengan baik, maka seluruh pegawai atau sumber daya yang dimiliki SKPD akan berjalan sesuai dengan harapan dan mampu menghasilkan laporan keuangan yang handal dan informatif. Pengelolaan terhadap keuangan yang terstruktur dan terperinci akan dapat memberikan keyakinan memadai atas laporan keuangan yang disajikan. Semaikn baik pengendalian internal pemerintah maka semaikin akuntabel dan transparan (E. W. Sari \& Azlina, 2017).

\section{KESIMPULAN}

Berdasarkan hasil penelitian analisis, maka disimpulkan beberapa hal sebagai berikut: 1) penyajian laporan keuangan dan aksesibilitas tidak berpengaruh terhadap transparansi dan akuntabilitas pengelolaan keuangan daerah; 2) Pengedalian internal berpengaruh positif signifikan terhadap transparansi dan akuntabilitas pengelolaan keuangan daerah.

\section{Keterbatasan \& Saran}

Berdasarkan penelitian yang telah dilakukan keterbatasan penelitian sebagai berikut: Pertama, sampel yang hanya berfokus dinas, badan, dan RSUD, penelitian ini tidak menggunakan keseluruhan SKPD yang ada di kabupaten Klaten. Saran untuk penelitian selanjutnya adalah dengan memperluas sampel penelitian karena semakin banyak sampel maka hasil penelitian akan semakin dapat digeneralisasi (Alharbi, 2014). Penelitian ini hanya meneliti variabel penyajian laporan keuangan, aksesibilitas dan sistem pengendalian internal. Saran untuk penelitian selanjutnya dengan menambahkan variabel misalnya umur pemerintah daerah, karena umur pemerintah daerah yang lama akan semakin berpengalaman dalam penyusunan laporan keuangan sehingga lebih transparan dan akuntabel (Naopal, Rahayu, \& Yudowati, 2017).

\section{DAFTAR PUSTAKA}

Aliyah, S., \& Nahar, A. (2012). Pengaruh Penyajian Laporan Keuangan Daerah Terhadap Transparansi dan Akuntabilitas Pengelolaan Keuangan Daerah Kabupaten Jepara. Jurnal Akuntansi \& Auditing, 8(2), 97-189.

Andriani, W. (2010). Pengaruh Kapasitas Sumber Daya Manusia dan Pemanfaatan Teknologi Informasi Terhadap Keterandalan dan Ketepatwaktuan Laporan Keuangan Pemerintah Daerah (Studi pada Pemerintah Daerah Kab. Pesisir Selatan). Jurnal Akuntansi \& Manajemen, 5(1), 69-80.

Andriyani, L., Nur, D., \& Anggraini, L. (2016). Pengaruh Tekanan Eksternal, Komitmen Manajemen, Ketidakpastian Lingkungan, Gaya Kepemimpinan, Dan Aksesibilitas Laporan Keuangan Terhadap Penerapan Transparansi Pelaporan Keuangan (Survei Pada Satuan Kerja Perangkat Daerah Pemerintah Kabupaten Pelalawan). Jurnal Online Mahasiswa Fakultas Ekonomi Universitas Riau, 3(1), 204-218.

Azlina, N., \& Hasan, M. A. (2016). Pengaruh Penyajian Laporan Keuangan dan Aksesibilitas Laporan Keuangan terhadap Akuntabilitas Pengelolaan Keuangan Daerah (Studi pada Skpd Kabupaten Bengkalis). Jurnal Online Mahasiswa Fakultas Ekonomi Universitas Riau, 3(1), 449-461. 
Budiarto, D. S. (2019). Panduan Riset Kuantitatif: Trik Publikasi Bagi Pemula (Edisi 1). In: UPY Press.

Grosso, A. L., \& Van Ryzin, G. G. (2011). How citizens view government performance reporting: Results of a national survey. Public Performance \& Management Review, 35(2), 235-250.

Hehanussa, S. J. (2015). Pengaruh Penyajian Laporan Keuangan Daerah dan Aksesibilitas Laporan Keuangan Daerah Terhadap Transparansi dan Akuntabilitas Pengelolaan Keuangan Daerah Kota Ambon. jurnal publikasi, 2(1), 82-90.

Ichlas, M., Basri, H., \& Arfan, M. (2014). Pengaruh Penerapan Standar Akuntansi Pemerintahan, Sistem Pengendalian Intern Pemerintah Dan Aksesibilitas Laporan Keuangan Terhadap Akuntabilitas Keuangan Pemerintah Kota Banda Aceh. Jurnal Administrasi Akuntansi: Program Pascasarjana Unsyiah, 3(4), 1-10.

Ledo, D., \& Ayem, S. (2017). Pengaruh Aspek-Aspek Manajemen Keuangan Daerah Terhadap Transparansi Pengelolaan Keuangan Daerah. Kajian Bisnis STIE Widya Wiwaha, 25(2), 161175 .

Masyhur, M., \& Silfi, A. (2017). Pengaruh Penyajian Laporan Keuangan Daerah, Aksesibilitas Laporan Keuangan Daerah dan Pengendalian Internal terhadap Transparansi dan Akuntabilitas Pengelolaankeuangan Daerah Kota Dumai. Jurnal Online Mahasiswa Fakultas Ekonomi Universitas Riau, 4(1), 1179-1192.

Naopal, F., Rahayu, S., \& Yudowati, S. P. (2017). Pengaruh Karaktersitik Daerah, Jumlah Penduduk, Temuan Audit, dan Opini Audit terhadap Pengungkapan Laporan Keuangan Pemerintah Daerah. Paper presented at the Assets.

Nugraha, D. S., \& Susanti, A. (2010). The influence of internal control system to the reliability of local government financial statement (Case study at Pemerintah Provinsi Jawa barat). Jurnal Ekonomi, Keuangan, Perbankan, dan Akuntansi, 2(2), 259-280.

Putri, F. E., Anisma, Y., \& Al Azhar, A. (2016). Pengaruh Penyajian Laporan Keuangan Daerah, Aksesibilitas Laporan Keuangan Daerah dan Tingkat Pengungkapan Sukarela Laporan Keuangan Daerah terhadap Akuntabilitas Pengelolaan Keuangan Daerah (Studi Empiris pada Skpd Provinsi Riau). Jurnal Online Mahasiswa (JOM) Bidang Ilmu Ekonomi, 4(1), 483-497.

Putri, F. E., Anisma, Y., \& Al Azhar, A. (2017). Pengaruh Penyajian Laporan Keuangan Daerah, Aksesibilitas Laporan Keuangan Daerah dan Tingkat Pengungkapan Sukarela Laporan Keuangan Daerah terhadap Akuntabilitas Pengelolaan Keuangan Daerah (Studi Empiris pada Skpd Provinsi Riau). Jurnal Online Mahasiswa Fakultas Ekonomi Universitas Riau, 4(1), 483 497.

Rahma, N., Agusti, R., \& Wiguna, M. (2018). Pengaruh Penyajian Laporan Keuangan Aksesibilitas Laporan Keuangan Dan Sistem Pengendalian Intern Pemerintah Terhadap Akuntabilitas Pengelolaan Keuangan Daerah (Studi Empiris Pada Opd Pemerintah Kabupaten Indragiri Hulu). Jurnal Online Mahasiswa (JOM) Bidang Ilmu Ekonomi, 4(2), 1-15.

Rasuli, M., \& Silfi, A. (2015). Pengaruh Penyajian Laporan Keuangan, Aksesibilitas Dan Sistem Akuntansi Keuangan Daerah Terhadap Akuntabilitas Pengelolaan Keuangan Daerah (Studi Empiris Pada Satuan Kerja Perangkat Daerah Kabupaten Sijunjung). Jurnal Online Mahasiswa Fakultas Ekonomi Universitas Riau, 4(1), 2015-2029.

Salle, A. (2016). Makna Transparansi Dalam Pengelolaan Keuangan Daerah. Keuda: Jurnal Kajian Ekonomi Dan Keuangan Daerah, 1(1), 1-19. 
Sande, P. (2013). Pengaruh penyajian laporan keuangan dan aksesibilitas laporan keuangan terhadap akuntabilitas pengelolaan keuangan daerah (Studi empiris pada pemerintah Provinsi Sumatera Barat). Jurnal Akuntansi, 1(1), 1-20.

Sari, D. (2012). Pengaruh pengendalian internal terhadap transparansi laporan keuangan Pemerintah Daerah. seminar akuntansi dan bisnis, 718-727.

Sari, E. W., \& Azlina, N. (2017). Pengaruh Sistem Pengendalian Intern, Penyajian Laporan Keuangan, Aksesibilitas Laporan Keuangan Dan Gaya Kepemimpinan Terhadap Transparansi Dan Akuntabilitas Pengelolaan Keuangan Daerah Di Kabupaten Indragiri Hulu. Jurnal Online Mahasiswa Fakultas Ekonomi Universitas Riau, 4(1), 571-585.

Yuliani, N. L. (2017). Pengaruh Penyajian Laporan Keuangan, Karakteristik Kualitatif, Aksesibilitas Dan Pengendalian Internal Terhadap Transparansi Laporan Keuangan Pemerintah Daerah. Jurnal Bisnis dan Ekonomi, 24(1), 1-14. 